\title{
Transcriptomic analysis of differentially expressed genes in leaves and roots of two alfalfa (Medicago sativa L.) cultivars with different salt tolerance
}

\author{
Surendra Bhattarai ${ }^{1}$, Yong-Bi Fu², Bruce Coulman ${ }^{1}$ Karen Tanino ${ }^{1}$, Chithra Karunakaran ${ }^{3}$ and Bill Biligetu ${ }^{{ }^{*}}$
}

\begin{abstract}
Background: Alfalfa (Medicago sativa L.) production decreases under salt stress. Identification of genes associated with salt tolerance in alfalfa is essential for the development of molecular markers used for breeding and genetic improvement.

Result: An RNA-Seq technique was applied to identify the differentially expressed genes (DEGs) associated with salt stress in two alfalfa cultivars: salt tolerant 'Halo' and salt intolerant 'Vernal'. Leaf and root tissues were sampled for RNA extraction at $0 \mathrm{~h}, 3 \mathrm{~h}$, and $27 \mathrm{~h}$ under $12 \mathrm{dS} \mathrm{m}^{-1}$ salt stress maintained by $\mathrm{NaCl}$. The sequencing generated a total of 381 million clean sequence reads and $84.8 \%$ were mapped on to the alfalfa reference genome. A total of 237 DEGs were identified in leaves and 295 DEGs in roots of the two alfalfa cultivars. In leaf tissue, the two cultivars had a similar number of DEGs at $3 \mathrm{~h}$ and $27 \mathrm{~h}$ of salt stress, with 31 and 49 DEGs for 'Halo', 34 and 50 for 'Vernal', respectively. In root tissue, 'Halo' maintained 55 and 56 DEGs at $3 \mathrm{~h}$ and $27 \mathrm{~h}$, respectively, while the number of DEGs decreased from 42 to 10 for 'Vernal'. This differential expression pattern highlights different genetic responses of the two cultivars to salt stress at different time points. Interestingly, 28 (leaf) and 31 (root) salt responsive candidate genes were highly expressed in 'Halo' compared to Vernal' under salt stress, of which 13 candidate genes were common for leaf and root tissues. About $60 \%$ of DEGs were assigned to known gene ontology (GO) categories. The genes were involved in transmembrane protein function, photosynthesis, carbohydrate metabolism, defense against oxidative damage, cell wall modification and protection against lipid peroxidation. Ion binding was found to be a key molecular activity for salt tolerance in alfalfa under salt stress.

Conclusion: The identified DEGs are significant for understanding the genetic basis of salt tolerance in alfalfa. The generated genomic information is useful for molecular marker development for alfalfa genetic improvement for salt tolerance.
\end{abstract}

Keywords: Alfalfa, Differentially expressed genes, Salt stress, Transcriptome

\footnotetext{
* Correspondence: bill.biligetu@usask.ca

'Department of Plant Sciences, College of Agriculture and Bioresources,

University of Saskatchewan, 51 Campus Drive, Saskatoon, SK S7N 5A8,

Canada

Full list of author information is available at the end of the article
}

(C) The Author(s). 2021 Open Access This article is licensed under a Creative Commons Attribution 4.0 International License, which permits use, sharing, adaptation, distribution and reproduction in any medium or format, as long as you give appropriate credit to the original author(s) and the source, provide a link to the Creative Commons licence, and indicate if changes were made. The images or other third party material in this article are included in the article's Creative Commons licence, unless indicated otherwise in a credit line to the material. If material is not included in the article's Creative Commons licence and your intended use is not permitted by statutory regulation or exceeds the permitted use, you will need to obtain permission directly from the copyright holder. To view a copy of this licence, visit http://creativecommons.org/licenses/by/4.0/ The Creative Commons Public Domain Dedication waiver (http://creativecommons.org/publicdomain/zero/1.0/) applies to the data made available in this article, unless otherwise stated in a credit line to the data. 


\section{Background}

Alfalfa (Medicago sativa L.) is an important forage legume in the world. Cultivated alfalfa is an outcrossing autotetraploid $(2 \mathrm{n}=4 \mathrm{x}=32)$ with a genome size of 800 $1000 \mathrm{Mb}$ [1]. Although alfalfa is regarded as moderately tolerant to salinity [2], alfalfa yield reduces by approximately $6-7 \%$ for each $\mathrm{dS} \mathrm{m}^{-1}$ increase above a salinity of $2 \mathrm{dS} \mathrm{m}^{-1}$ [3]. To stabilize alfalfa production under saline regions, the development of superior salt tolerant cultivars becomes an important breeding goal. Identification of candidate genes for salt tolerance can increase the accuracy of parental selection as this trait has low heritability [4]. Salt tolerance is a complex trait controlled by multiple genes, involving different signaling pathways, osmotic tolerance, ion transport, compartmentalization of salt ions in vacuoles, the synthesis of plant hormones and photosynthesis [5].

Next-generation sequencing technologies have been used to identify candidate genes involved in salt tolerance of alfalfa. Transcriptomic studies in the 1-week old root tissue of alfalfa under salt stress found 1165 DEGs, including 86 transcription factors, which are responsible for stress tolerance, kinase, hydrolase, and oxidoreductase activities [6]. Luo et al. [7] identified 8861 DEGs in 12-day old seedlings of alfalfa under salt stress, which are responsible for ion homeostasis, antiporter, signal perception, signal transduction, transcriptional regulation, and antioxidative defense. Lei et al. [8] revealed 2237 DEGs between salt tolerant and intolerant alfalfa cultivars and found a salt tolerant alfalfa cultivar maintained relatively stable expression of genes responsible for reactive oxygen species and $\mathrm{Ca}^{2+}$ pathway, phytohormone biosynthesis and $\mathrm{Na}^{+} / \mathrm{K}^{+}$transport under stress. Gruber et al. [9], using bulked genotypes as replications, studied transcriptomes in alfalfa and found genes responsible for numerous functions in a salt intolerant alfalfa cultivar. In recent years, genetic modification of certain genes controlling salt tolerance have also been conducted in alfalfa. Overexpression of salt responsive genes or transcription factors had improved salt tolerance in transgenic alfalfa. Such genes include Alfin1 [10], AVP1 [11], GmDREB1 [12], SsNHX1 [13], TaNHX2 [14], GsCBRLK [15], GsZFP1 [16], OsAPX2 [17], SeNHX1 [18], AtNDPK2 [19], AgcodA [20], and GsWRKY20 [21]. These studies have advanced our understanding of the genetic control for salt tolerance in alfalfa. However, most studies mainly focused on single time point sampling of root tissue at the seedling stage after salt stress, limiting the analysis of the temporal expression of genes affecting salt tolerance.

Tissue specific protein induction is regulated during salinity stress and is unique to roots and shoots [22]. Thus, there should be tissue specific transcriptomic responses [23-25]. Although the root is the first receptor of salt stress [6,7], leaf tissue is the main energy source for plant growth and stress tolerance during active growth and developmental stages. To advance our knowledge about the temporal gene expression in different tissues for the genetic control under salt stress between tolerant and intolerant cultivars, we conducted a RNA-Seq analysis with the objective to simultaneously analyze gene expressions of leaf and root tissues of two alfalfa cultivars with different tolerance to salinity after exposing them to $12 \mathrm{dS} \mathrm{m} \mathrm{m}^{-1}$ of electrical conductivity salt stress for $0 \mathrm{~h}, 3 \mathrm{~h}$, and $27 \mathrm{~h}$. The analysis was fruitful with the identification of many unique genes conditioning salt tolerance in alfalfa.

\section{Results}

\section{High throughput sequencing and assembly}

A total of 408 million raw sequence reads were generated using the Illumina HiSeq sequencing platform. The reads were reduced to $93.5 \%$ (381 million clean reads) by removing adapter contamination and reads with length lower than $36 \mathrm{bp}$ (Table 1). There were $84.8 \%$ of clean reads mapped to the alfalfa reference genome using STAR (v2.6.1a). The samples showed high percentages (78.8-92.4\%) of mapping with the alfalfa reference genome except for 'Halo' root tissue sampled at 27 h of salt stress.

\section{Differentially expressed genes (DEGs)}

In leaf tissue, there were 237 DEGs identified between the two alfalfa cultivars. Among them, 34 DEGs were expressed at all three time points $(0 \mathrm{~h}, 3 \mathrm{~h}$, and $27 \mathrm{~h})$ and 17 DEGs expressed after exposing to salt stress ( $3 \mathrm{~h}$ and $27 \mathrm{~h}$ ) (Fig. 1a, b; Additional file 1: Table S1). Of these DEGs, 39, 31, and 49 DEGs were specific to 'Halo', and 34,34 , and 50 DEGs were specific to 'Vernal' at $0 \mathrm{~h}, 3 \mathrm{~h}$ and $27 \mathrm{~h}$ of salt stress, respectively (Fig. 1b). The number of DEGs in leaf tissue decreased after $3 \mathrm{~h}$ compared to 0 $h$ treatment. Then, the number of DEGs increased from $3 \mathrm{~h}$ to $27 \mathrm{~h}$ of salt stress for both cultivars (Fig. 1b).

In root tissue, a total of 295 DEGs were identified between the two alfalfa cultivars. There were 33 DEGs expressed at all three time points and 5 DEGs expressed after exposing to salt stress (Fig. 2a, b; Additional file 1: Table S2). Of these DEGs, 68, 55, and 56 DEGs were specific to 'Halo' at $0 \mathrm{~h}, 3 \mathrm{~h}$ and $27 \mathrm{~h}$, whereas 64, 42, and 10 DEGs were specific to 'Vernal', respectively (Fig. $2 b)$. The number of DEGs in root tissue decreased at $3 \mathrm{~h}$ as compared to $0 \mathrm{~h}$ treatment for both cultivars, but the decrease was greater for 'Vernal' than for 'Halo'. The main difference of DEGs between the two cultivars in the root was from $3 \mathrm{~h}$ to $27 \mathrm{~h}$, with a $76 \%$ decrease in DEGs in 'Vernal' while there was almost no change for 'Halo' (Fig. 2b). After $27 \mathrm{~h}$ of salt stress in root tissue, 
Table 1 Summary of Illumina sequencing data and mapped sequence reads for the assayed alfalfa samples

\begin{tabular}{|c|c|c|c|c|c|c|}
\hline Genotype & Tissue & Treatment & Biological replicate & Total reads & Mapped reads & Mapping rate (\%) \\
\hline \multirow[t]{24}{*}{ Halo } & \multirow[t]{12}{*}{ Leaf } & Control & 1 & $7,235,661$ & $6,275,026$ & 86.7 \\
\hline & & Control & 2 & $7,462,991$ & $6,607,722$ & 88.5 \\
\hline & & Control & 3 & $7,532,603$ & $6,371,474$ & 84.6 \\
\hline & & Control & 4 & $7,163,647$ & $6,286,906$ & 87.8 \\
\hline & & Stressed (3h) & 1 & $7,170,087$ & $6,291,489$ & 87.7 \\
\hline & & Stressed (3h) & 2 & $8,619,083$ & $7,531,679$ & 87.4 \\
\hline & & Stressed (3h) & 3 & $7,275,223$ & $6,453,594$ & 88.7 \\
\hline & & Stressed (3h) & 4 & $7,346,150$ & $6,417,574$ & 87.4 \\
\hline & & Stressed (27h) & 1 & $7,234,036$ & $5,968,374$ & 82.5 \\
\hline & & Stressed (27h) & 2 & $7,186,154$ & $6,225,839$ & 86.6 \\
\hline & & Stressed (27h) & 3 & $6,256,894$ & $5,471,745$ & 87.5 \\
\hline & & Stressed (27h) & 4 & $5,696,229$ & $4,741,642$ & 83.2 \\
\hline & \multirow[t]{12}{*}{ Root } & Control & 1 & $7,930,008$ & $6,833,311$ & 86.2 \\
\hline & & Control & 2 & $7,568,654$ & $6,104,814$ & 80.7 \\
\hline & & Control & 3 & $10,017,590$ & $9,054,027$ & 90.4 \\
\hline & & Control & 4 & $6,523,142$ & $5,561,719$ & 85.3 \\
\hline & & Stressed (3h) & 1 & $9,003,316$ & $7,662,274$ & 85.1 \\
\hline & & Stressed (3h) & 2 & $11,023,879$ & $9,201,753$ & 83.5 \\
\hline & & Stressed (3h) & 3 & $9,647,653$ & $8,529,106$ & 88.4 \\
\hline & & Stressed (3h) & 4 & $6,201,499$ & $4,884,633$ & 78.8 \\
\hline & & Stressed (27h) & 1 & $6,563,910$ & $4,983,668$ & 75.9 \\
\hline & & Stressed (27h) & 2 & $8,321,924$ & $3,727,203$ & 44.8 \\
\hline & & Stressed (27h) & 3 & $9,424,651$ & $7,313,948$ & 77.6 \\
\hline & & Stressed (27h) & 4 & $7,942,407$ & $2,854,933$ & 35.9 \\
\hline \multirow[t]{20}{*}{ Vernal } & \multirow[t]{12}{*}{ Leaf } & Control & 1 & $7,085,736$ & $6,147,440$ & 86.8 \\
\hline & & Control & 2 & $7,149,929$ & $6,449,664$ & 90.2 \\
\hline & & Control & 3 & $8,108,009$ & $7,362,827$ & 90.8 \\
\hline & & Control & 4 & $10,775,421$ & $9,953,409$ & 92.4 \\
\hline & & Stressed (3h) & 1 & $5,372,062$ & $4,901,710$ & 91.2 \\
\hline & & Stressed (3h) & 2 & $6,180,723$ & $5,477,930$ & 88.6 \\
\hline & & Stressed (3h) & 3 & $7,355,464$ & $6,390,995$ & 86.9 \\
\hline & & Stressed (3h) & 4 & $6,775,443$ & $6,098,490$ & 90.0 \\
\hline & & Stressed (27h) & 1 & $11,398,645$ & $10,388,765$ & 91.1 \\
\hline & & Stressed (27h) & 2 & $7,517,258$ & $6,754,908$ & 89.9 \\
\hline & & Stressed (27h) & 3 & $8,128,644$ & $7,280,110$ & 89.6 \\
\hline & & Stressed (27h) & 4 & $7,713,476$ & $7,007,553$ & 90.8 \\
\hline & \multirow[t]{8}{*}{ Root } & Control & 1 & $11,004,685$ & $9,744,748$ & 88.6 \\
\hline & & Control & 2 & $10,402,513$ & $9,091,041$ & 87.4 \\
\hline & & Control & 3 & $8,070,744$ & $7,001,864$ & 86.8 \\
\hline & & Control & 4 & $8,936,244$ & $7,616,107$ & 85.2 \\
\hline & & Stressed (3h) & 1 & $8,293,827$ & $7,159,751$ & 86.3 \\
\hline & & Stressed (3h) & 2 & $8,722,568$ & $7,705,076$ & 88.3 \\
\hline & & Stressed (3h) & 3 & $9,769,559$ & $8,854,805$ & 90.6 \\
\hline & & Stressed (3h) & 4 & $6,402,547$ & $5,317,429$ & 83.1 \\
\hline
\end{tabular}


Table 1 Summary of Illumina sequencing data and mapped sequence reads for the assayed alfalfa samples (Continued)

\begin{tabular}{|c|c|c|c|c|c|c|}
\hline Genotype & Tissue & Treatment & Biological replicate & Total reads & Mapped reads & Mapping rate (\%) \\
\hline & & Stressed (27h) & 1 & $3,669,213$ & $3,121,348$ & 85.1 \\
\hline & & Stressed (27h) & 2 & $9,000,614$ & $7,858,878$ & 87.3 \\
\hline & & Stressed (27h) & 3 & $8,661,229$ & $7,569,795$ & 87.4 \\
\hline & & Stressed (27h) & 4 & $8,640,454$ & $7,481,651$ & 86.6 \\
\hline \multicolumn{4}{|l|}{ Total } & $381,482,398$ & $324,090,747$ & \\
\hline \multicolumn{4}{|c|}{ Average (Control) } & $8,310,474$ & $7,278,881$ & 87.4 \\
\hline \multicolumn{4}{|c|}{ Average (3 h) } & $7,882,443$ & $6,804,893$ & 87.0 \\
\hline \multicolumn{4}{|c|}{ Average (27 h) } & $7,709,734$ & $6,171,898$ & 80.1 \\
\hline \multicolumn{4}{|l|}{ Average } & $7,947,550$ & $6,751,891$ & 84.8 \\
\hline
\end{tabular}

the number of DEGs in 'Halo' were five times more than that of 'Vernal' (Fig. 2b).

\section{Functional annotation of DEGs}

To understand what biological processes are implicated in response to salinity, we assigned the DEGs to known Gene Ontology (GO) categories. Among 237 DEGs in leaf tissue, $148(62.4 \%)$ DEGs were assigned to three ontology classes. In 'Halo' leaf tissue, the most noticeable DEGs [false discovery rate $(\mathrm{FDR})<0.05$ ] were "drug binding" (GO:0008144, 5), "anion binding" (GO: 0043168, 8), "ion binding" (GO:0043167, 15) and "catalytic activity" (GO:0003824, 24) among molecular functions (Fig. 3a) while there was no significantly enriched functional groups from biological process and cellular component. For 'Vernal' leaf tissue, "cofactor binding" (GO:0048037, 7) and "oxidoreductase activity" (GO: 0016491, 11) were predominant (FDR <0.05) among molecular functions (Fig. 3b) and "oxidation-reduction process" (GO:0055114, 10) (Fig. 3c) in biological process, but there was not any significantly enriched functional groups from cellular component.

Among the 295 DEGs in root tissue, 180 (61.0\%) DEGs were annotated to three gene ontology classes. In root tissue of 'Halo', "anion binding" (GO:0043168, 9), "ion binding" (GO:0043167, 18), "structural constituent of ribosome" (GO:0003735, 7), and "structural molecule activity" (GO:0005198, 7) among molecular functions (Fig. 4a) were noticeable, while "organo-nitrogen compound metabolic process" (GO:1901564, 15) was dominant among biological processes (Fig. 4b). "Ribosome" (GO:0005840, 7), "ribonucleoprotein complex" (GO:1990904, 8), "intracellular ribonucleoprotein complex" (GO:0030529, 8) were predominant in cellular components (Fig. 4c). For root tissue of 'Vernal', "anion binding" (GO:0043168, 9) and "drug binding" (GO:0008144, 5) (Fig. 4d) were significantly (FDR <0.05) enriched, while no other functional group from biological processes and cellular components.
To identify pathways involved in salt tolerance, we carried out Kyoto Encyclopedia of Genes and Genomes (KEGG) pathways analysis of the DEGs. In total, 64 (27\%) DEGs from leaf tissue and 86 (29.15\%) DEGs from root tissue were assigned to 65 KEGG pathways (Table 2 ). In both tissues, the most significant DEGs were represented in the pathways of metabolism and biosynthesis of secondary metabolites. Of these, five pathways were common among different time points and alfalfa tissues. The highest level of enriched DEGs were in 14 pathways in leaf tissue and 6 pathways in root tissue after $27 \mathrm{~h}$ of salt stress. Among these pathways, the three highest enriched DEGs were involved in plant hormone signal transduction.

\section{Candidate genes to enhance salt tolerance in alfalfa}

The detected DEGs can be classified into two major groups for the candidate genes responsible for salt tolerance in alfalfa: 1) genes consistently expressed under short-term and long-term salt stress ( $3 \mathrm{~h}$ and $27 \mathrm{~h}$ ) in 'Halo', and 2) the genes consistently expressed at all three time points in 'Halo'. In the first group, there were 13 genes (11 in leaf; 2 in root) consistently expressed at both $3 \mathrm{~h}$ and $27 \mathrm{~h}$ of salt stress. While in the second group, there were 46 genes (17 in leaf, 29 in root) consistently expressed at all three time points. Thirteen candidate genes were highly expressed in both leaf and root tissues of 'Halo' as compared to 'Vernal', while 15 and 18 candidate genes revealed tissue specific expression in the leaf and root tissues of 'Halo', respectively (Tables 3, 4, and 5). Among the genes expressed in both tissues, MS.gene029203 (F-box/LRR-repeat protein 4) showed increasing expression with time in both leaf and root tissues of 'Halo', while MS.gene049294 (caffeic acid 3-Omethyltransferase) showed increasing expression with time in leaf tissue and MS.gene01091 (T-complex protein 1 subunit gamma) and MS.gene32989 (hypothetical protein TSUD_06780) showed increasing expression with time only in root tissue. Among the genes with leaf tissue specific expression, MS.gene029201 (replication 

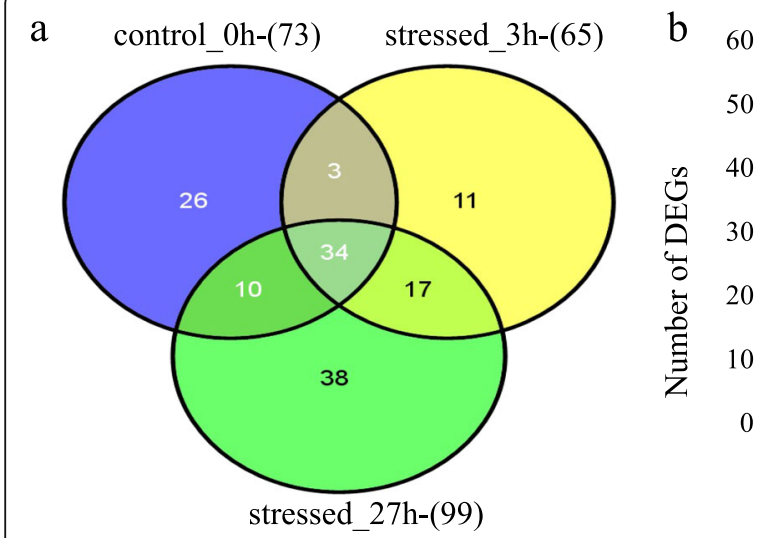

Fig. 1 Differentially expressed genes (DEGs) between salt tolerant 'Halo' and intolerant 'Vernal' alfalfa cultivars in leaf tissue at three different timepoints: control $(0 \mathrm{~h}), 3 \mathrm{~h}$ and $27 \mathrm{~h}$ after salt stress. a Venn diagram for number of DEGs in leaf tissue of two alfalfa cultivars ('Halo' vs. 'Vernal') at three different time-points $(0 \mathrm{~h}, 3 \mathrm{~h}$, and $27 \mathrm{~h})$. Number in the parenthesis represents total number of DEGs. Numbers in each intersection represent the number of DEGs detected in two or three time points. b Number of DEGs identified in leaf tissue at each time-point $(0 \mathrm{~h}, 3 \mathrm{~h}$, and $27 \mathrm{~h}$ ) between tolerant and intolerant alfalfa cultivars

protein A $70 \mathrm{kDa}$ DNA-binding subunit C), MS.gene029206 (FAD synthetase 1, chloroplastic), and MS.gene24098 (thioredoxin-like protein CDSP32 chloroplastic-like) showed increasing expression with time. Among the genes with root tissue specific expression, MS.gene011517 (14 kDa proline-rich protein DC2.15) and MS.gene013923 (histone lysine Nmethyltransferase, H3 lysine-9 specific SUVH1), had higher and consistent expression with time under salt stress.

In addition, there were also genes consistently expressed under salt stress in leaf (Additional file 1: Table S1) and root (Additional file 1: Table S2) tissues of 'Vernal'. In 'Vernal', there were 21 (17 in leaf; 4 in root) genes consistently expressed at all three time points and 9 (6 in leaf; 3 in root) genes consistently expressed at both $3 \mathrm{~h}$ and $27 \mathrm{~h}$ of salt stress.

Identification of single nucleotide polymorphisms (SNPs) The relative distribution of identified SNPs over alfalfa chromosome are presented in Fig. 5. A total of 74,705 SNPs were identified in this study, among which 37,527 were from 'Halo' and 37,178 were from 'Vernal'. Minimum number of SNPs were found in Chr6.4 while maximum number of SNPs were detected in Chr4.4 (Fig. 5).
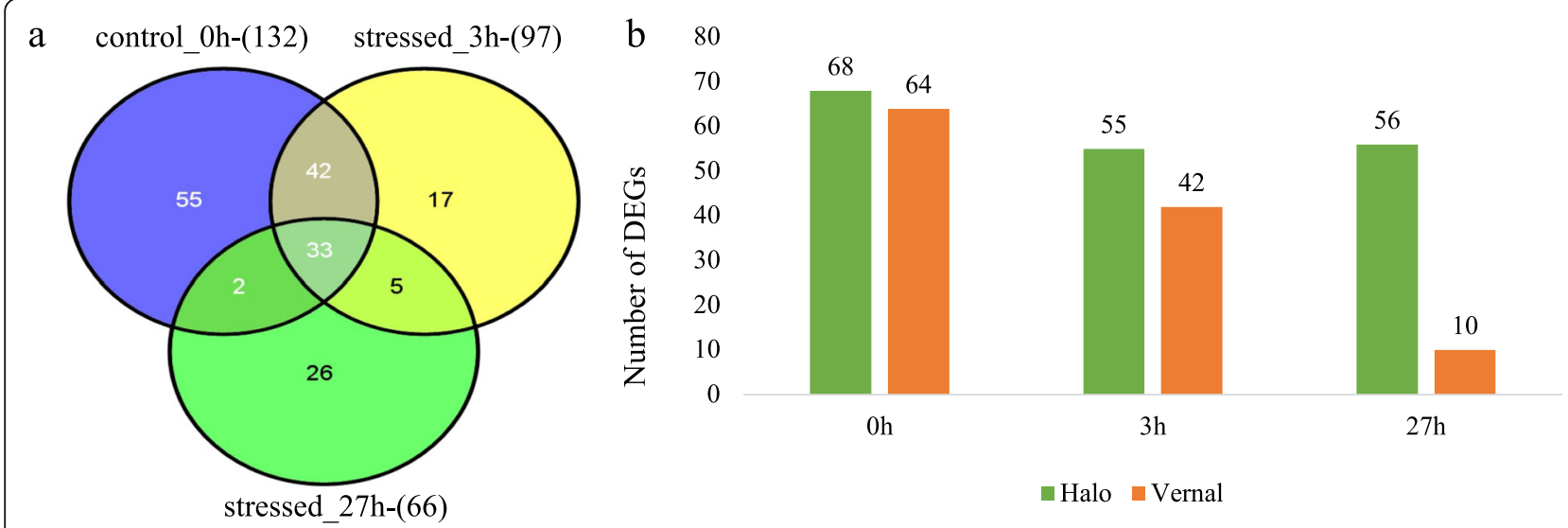

Fig. 2 Differentially expressed genes (DEGs) between salt tolerant 'Halo' and intolerant Vernal' alfalfa cultivars in root tissue at three different time-points: control ( $0 \mathrm{~h}$ ), $3 \mathrm{~h}$ and $27 \mathrm{~h}$ after salt stress. a Venn diagram for number of DEGs in root tissue of two alfalfa cultivars ('Halo' vs. 'Vernal') at three different time-points $(0 \mathrm{~h}, 3 \mathrm{~h}$, and $27 \mathrm{~h})$. Number in the parenthesis represents total number of DEGs. Numbers in each intersection represent the number of DEGs detected in two or three time points. b number of DEGs identified in root tissue at each time-point ( $0 \mathrm{~h}$, $3 \mathrm{~h}, 27 \mathrm{~h}$ ) between tolerant and intolerant alfalfa cultivars 


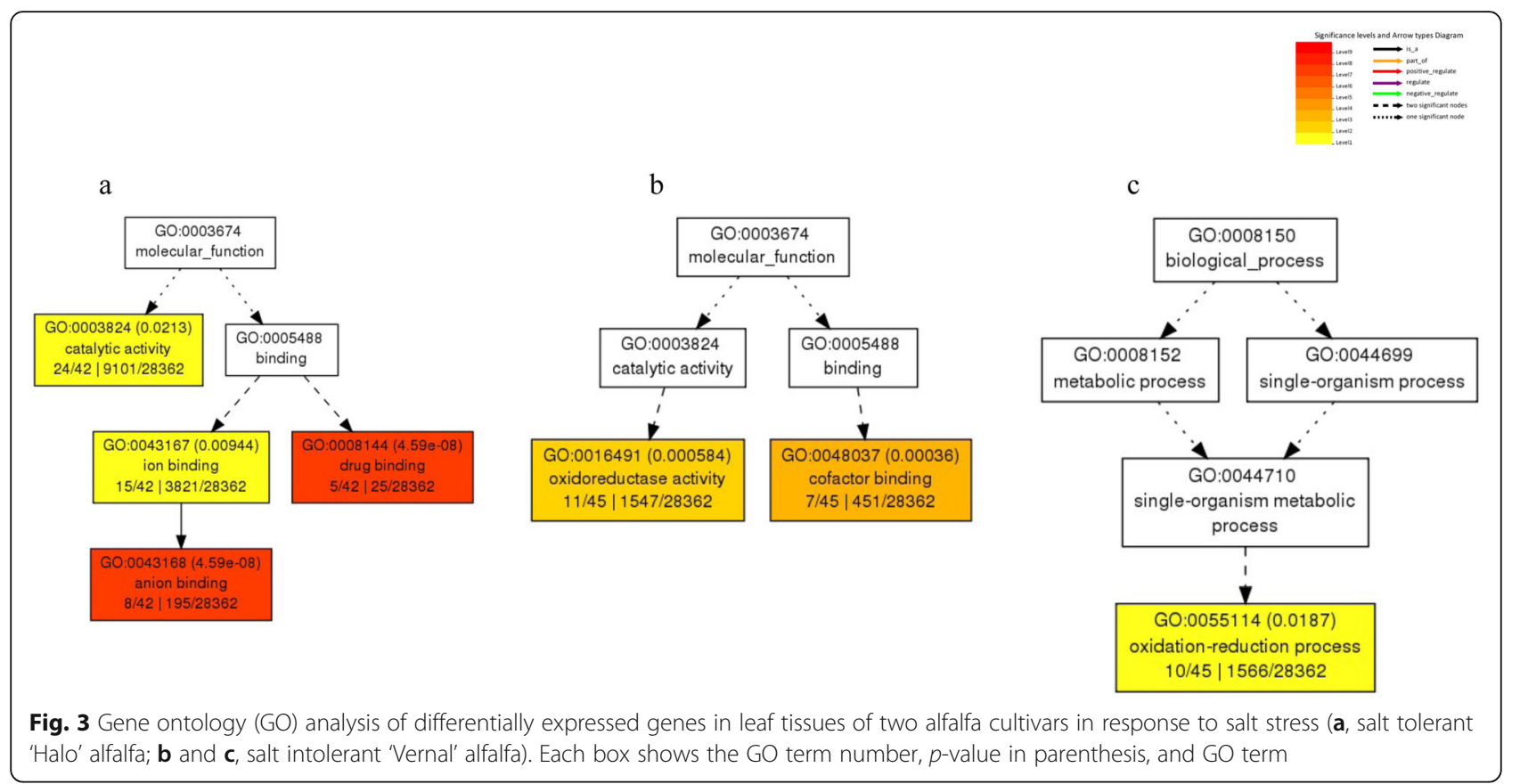

\section{Discussion}

This study generated a unique set of differentially expressed genes associated with salt tolerance in alfalfa. This finding is not only significant for understanding the temporal expression of genes conditioning salt tolerance in alfalfa, but also can be used to characterize alfalfa breeding material and develop molecular markers for salt tolerance selection. First, $84.8 \%$ of sequence reads were mapped onto the alfalfa reference genome. Secondly, 237 DEGs in leaf and 295 DEGs in root tissues were identified between the two alfalfa cultivars. Third, this study was able to determine candidate genes

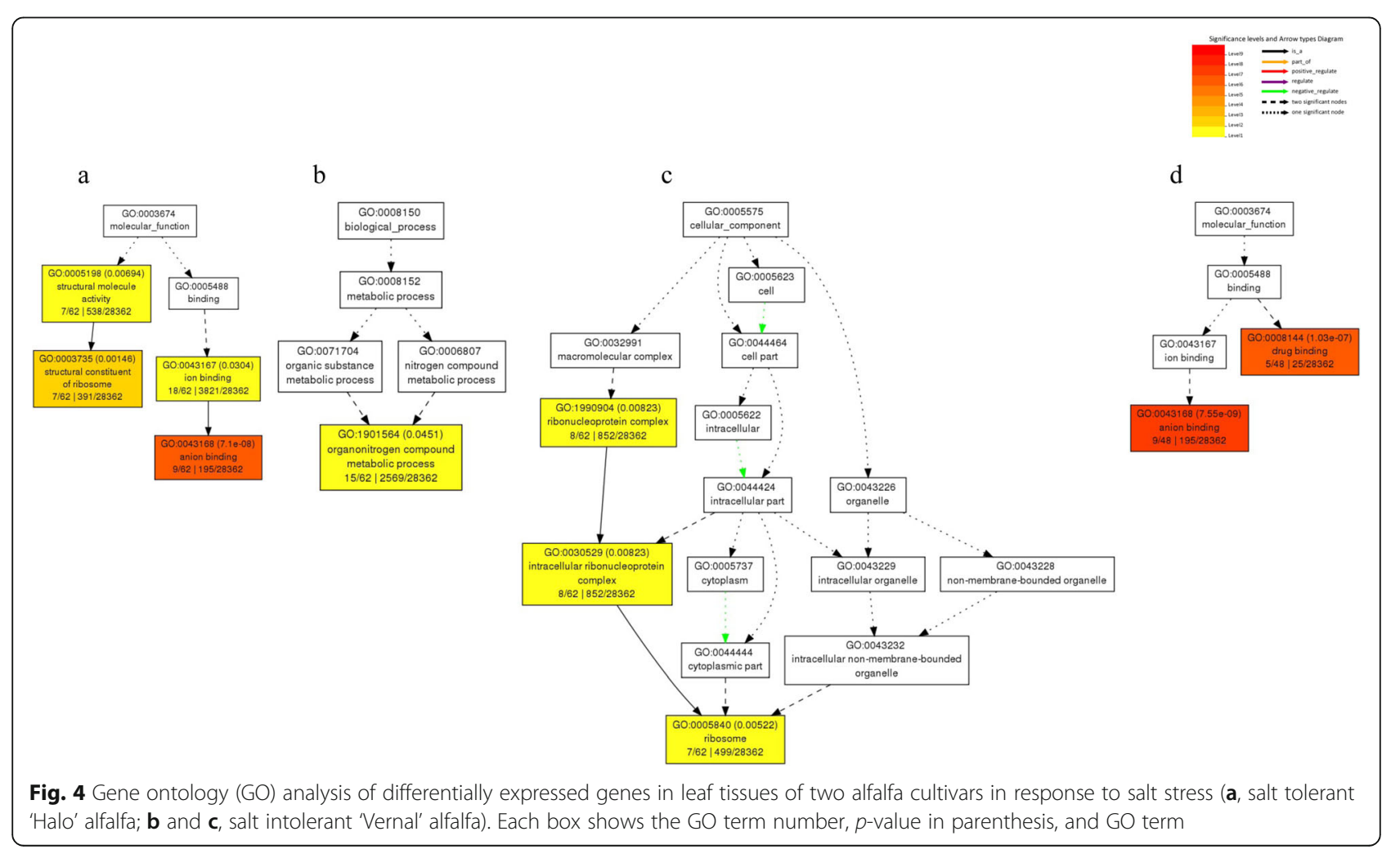


Table 2 Number of differentially expressed genes (DEGs) and corresponding pathways in leaf and root of salt tolerant 'Halo' and salt intolerant 'Vernal' alfalfa cultivars at 0, 3 and $27 \mathrm{~h}$ of salt stress

\begin{tabular}{|c|c|c|c|c|c|c|c|}
\hline \multirow{2}{*}{$\begin{array}{l}\text { Pathway } \\
\text { ID }\end{array}$} & \multicolumn{6}{|c|}{ The number of differentially expressed genes } & \multirow[t]{2}{*}{ Pathway terms } \\
\hline & HLOvsVLO & HL3vsVL3 & HL27vsVL27 & HROvsVRO & HR3vsVR3 & HR27vsVR27 & \\
\hline K00130 & 0 & 0 & 0 & 1 & 1 & 1 & betB, gbsA; betaine-aldehyde dehydrogenase \\
\hline K00276 & 0 & 0 & 1 & 0 & 0 & 0 & AOC3, AOC2, tynA; primary-amine oxidase \\
\hline K00430 & 0 & 0 & 1 & 0 & 0 & 0 & E1.11.1.7; peroxidase \\
\hline K00454 & 0 & 0 & 1 & 0 & 0 & 0 & LOX2S; lipoxygenase \\
\hline K00522 & 0 & 0 & 1 & 0 & 0 & 0 & FTH1; ferritin heavy chain \\
\hline K00549 & 1 & 1 & 1 & 1 & 1 & 1 & $\begin{array}{l}\text { metE; 5-methyltetrahydropteroyltriglutamate-- } \\
\text { homocysteine methyltransferase }\end{array}$ \\
\hline K00660 & 0 & 0 & 0 & 0 & 0 & 1 & CHS; chalcone synthase \\
\hline K00915 & 0 & 0 & 0 & 1 & 0 & 0 & IPMK, IPK2; inositol-polyphosphate multikinase \\
\hline K01507 & 0 & 0 & 0 & 1 & 1 & 1 & ppa; inorganic pyrophosphatase \\
\hline K01535 & 0 & 0 & 1 & 1 & 0 & 0 & PMA1, PMA2; H+-transporting ATPase \\
\hline K01623 & 0 & 0 & 0 & 1 & 1 & 0 & ALDO; fructose-bisphosphate aldolase, class I \\
\hline K01823 & 1 & 1 & 1 & 1 & 1 & 0 & idi, IDI; isopentenyl-diphosphate Delta-isomerase \\
\hline K01859 & 0 & 0 & 0 & 0 & 0 & 1 & E5.5.1.6; chalcone isomerase \\
\hline K02639 & 1 & 1 & 2 & 1 & 1 & 0 & petF; ferredoxin \\
\hline K02721 & 1 & 0 & 1 & 0 & 0 & 0 & psbW; photosystem II PsbW protein \\
\hline K02893 & 1 & 0 & 0 & 1 & 2 & 1 & RP-L23Ae, RPL23A; large subunit ribosomal protein L23Ae \\
\hline K02906 & 0 & 0 & 1 & 0 & 0 & 0 & RP-L3, MRPL3, rplC; large subunit ribosomal protein L3 \\
\hline K02925 & 0 & 0 & 1 & 0 & 0 & 0 & RP-L3e, RPL3; large subunit ribosomal protein $L 3 e$ \\
\hline K02971 & 0 & 0 & 1 & 1 & 1 & 0 & RP-S21e, RPS21; small subunit ribosomal protein S21e \\
\hline K02981 & 0 & 0 & 0 & 1 & 0 & 0 & RP-S2e, RPS2; small subunit ribosomal protein S2e \\
\hline K02985 & 1 & 0 & 0 & 0 & 0 & 0 & RP-S3e, RPS3; small subunit ribosomal protein S3e \\
\hline K02991 & 0 & 0 & 0 & 1 & 1 & 0 & RP-S6e, RPS6; small subunit ribosomal protein S6e \\
\hline K03231 & 2 & 2 & 2 & 2 & 2 & 2 & EEF1A; elongation factor 1-alpha \\
\hline K03283 & 0 & 0 & 0 & 0 & 0 & 1 & HSPA1s; heat shock 70kDa protein 1/2/6/8 \\
\hline K03364 & 0 & 0 & 1 & 0 & 0 & 0 & $\begin{array}{l}\text { CDH1; cell division cycle 20-like protein 1, cofactor of } \\
\text { APC complex }\end{array}$ \\
\hline K05546 & 0 & 0 & 0 & 1 & 1 & 0 & GANAB; mannosyl-oligosaccharide alpha-1,3-glucosidase \\
\hline K06617 & 0 & 0 & 0 & 0 & 1 & 0 & E2.4.1.82; raffinose synthase \\
\hline K07374 & 0 & 0 & 0 & 1 & 0 & 0 & TUBA; tubulin alpha \\
\hline K07466 & 1 & 1 & 1 & 1 & 1 & 0 & RFA1, RPA1, rpa; replication factor A1 \\
\hline K08678 & 0 & 0 & 0 & 1 & 0 & 0 & UXS1, uxs; UDP-glucuronate decarboxylase \\
\hline K09495 & 1 & 1 & 1 & 1 & 1 & 1 & CCT3, TRIC5; T-complex protein 1 subunit gamma \\
\hline K09588 & 0 & 1 & 0 & 0 & 0 & 0 & CYP90A1, CPD; cytochrome P450 family 90 subfamily A1 \\
\hline K09645 & 0 & 0 & 0 & 1 & 0 & 0 & CPVL; vitellogenic carboxypeptidase-like protein \\
\hline K10534 & 0 & 0 & 0 & 0 & 1 & 0 & NR; nitrate reductase $(\mathrm{NAD}(\mathrm{P}) \mathrm{H})$ \\
\hline K10573 & 0 & 0 & 0 & 0 & 0 & 1 & UBE2A, UBC2, RAD6A; ubiquitin-conjugating enzyme E2 A \\
\hline K10767 & 0 & 0 & 0 & 1 & 0 & 0 & ALKBH5; mRNA N6-methyladenine demethylase \\
\hline K11717 & 0 & 0 & 0 & 0 & 0 & 1 & sufS; cysteine desulfurase / selenocysteine lyase \\
\hline K12130 & 0 & 1 & 1 & 0 & 0 & 0 & PRR5; pseudo-response regulator 5 \\
\hline K12236 & 1 & 1 & 1 & 1 & 1 & 1 & NFX1; transcriptional repressor NF-X1 \\
\hline K12741 & 0 & 0 & 0 & 0 & 1 & 0 & $\begin{array}{l}\text { HNRNPA1_3; heterogeneous nuclear ribonucleoprotein } \\
\text { A1/A3 }\end{array}$ \\
\hline
\end{tabular}


Table 2 Number of differentially expressed genes (DEGs) and corresponding pathways in leaf and root of salt tolerant 'Halo' and salt intolerant 'Vernal' alfalfa cultivars at 0, 3 and $27 \mathrm{~h}$ of salt stress (Continued)

\begin{tabular}{|c|c|c|c|c|c|c|c|}
\hline \multirow{2}{*}{$\begin{array}{l}\text { Pathway } \\
\text { ID }\end{array}$} & \multicolumn{6}{|c|}{ The number of differentially expressed genes } & \multirow[t]{2}{*}{ Pathway terms } \\
\hline & HLOvsVL0 & HL3vsVL3 & HL27vsVL27 & HROvsVRo & HR3vsVR3 & HR27vsVR27 & \\
\hline K12891 & 0 & 1 & 0 & 0 & 0 & 0 & SFRS2; splicing factor, arginine/serine-rich 2 \\
\hline K13946 & 0 & 0 & 1 & 1 & 1 & 0 & AUX1, LAX; auxin influx carrier (AUX1 LAX family) \\
\hline K13963 & 0 & 0 & 0 & 1 & 1 & 0 & SERPINB; serpin B \\
\hline K14315 & 0 & 1 & 1 & 1 & 1 & 0 & NDC1, TMEM48; nucleoporin NDC1 \\
\hline K14404 & 0 & 0 & 0 & 0 & 1 & 0 & $\begin{array}{l}\text { CPSF4, YTH1; cleavage and polyadenylation specificity } \\
\text { factor subunit } 4\end{array}$ \\
\hline K14488 & 0 & 0 & 0 & 0 & 1 & 0 & SAUR; SAUR family protein \\
\hline K14504 & 0 & 0 & 0 & 0 & 0 & 1 & TCH4; xyloglucan:xyloglucosyl transferase TCH4 \\
\hline K14568 & 0 & 0 & 1 & 1 & 1 & 1 & $\begin{array}{l}\text { EMG1, NEP1; rRNA small subunit pseudouridine } \\
\text { methyltransferase Nep1 }\end{array}$ \\
\hline K14842 & 0 & 0 & 0 & 1 & 0 & 0 & NSA2; ribosome biogenesis protein NSA2 \\
\hline K15281 & 0 & 0 & 0 & 1 & 0 & 0 & SLC35D; solute carrier family 35 \\
\hline K15378 & 0 & 1 & 0 & 0 & 1 & 0 & SLC45A1_2_4; solute carrier family 45 , member $1 / 2 / 4$ \\
\hline K15397 & 1 & 0 & 0 & 0 & 0 & 0 & KCS; 3-ketoacyl-CoA synthase \\
\hline K15747 & 1 & 0 & 1 & 0 & 0 & 0 & LUT5, CYP97A3; beta-ring hydroxylase \\
\hline K16298 & 0 & 0 & 1 & 1 & 1 & 0 & SCPL-IV; serine carboxypeptidase-like clade IV \\
\hline K17525 & 1 & 0 & 1 & 0 & 0 & 0 & CHID1; chitinase domain-containing protein 1 \\
\hline K17592 & 0 & 0 & 0 & 0 & 1 & 0 & SACS; sacsin \\
\hline K17679 & 0 & 0 & 0 & 1 & 0 & 0 & $\begin{array}{l}\text { MSS116; ATP-dependent RNA helicase MSS116, } \\
\text { mitochondrial }\end{array}$ \\
\hline K18270 & 0 & 0 & 0 & 1 & 0 & 0 & $\begin{array}{l}\text { RAB3GAP1; Rab3 GTPase-activating protein catalytic } \\
\text { subunit }\end{array}$ \\
\hline K18857 & 0 & 0 & 0 & 1 & 1 & 0 & ADH1; alcohol dehydrogenase class-P \\
\hline K20471 & 0 & 0 & 1 & 0 & 0 & 0 & COPD, ARCN1, RET2; coatomer subunit delta \\
\hline K20628 & 1 & 0 & 0 & 0 & 1 & 0 & exIX; expansin \\
\hline K20726 & 0 & 1 & 1 & 1 & 1 & 1 & TMEM222; transmembrane protein 222 \\
\hline K21797 & 0 & 0 & 1 & 1 & 0 & 0 & SAC1, SACM1L; phosphatidylinositol 4-phosphatase \\
\hline K23050 & 1 & 1 & 1 & 1 & 1 & 0 & PCBER1; phenylcoumaran benzylic ether reductase \\
\hline K23570 & 1 & 1 & 1 & 1 & 1 & 1 & EMC10; ER membrane protein complex subunit 10 \\
\hline
\end{tabular}

HLO Halo leaf control, VLO Vernal leaf control, HL3 Halo leaf after $3 \mathrm{~h}$ of salt stress, VL3 Vernal leaf after $3 \mathrm{~h}$ of salt stress, HL27 Halo leaf after $27 \mathrm{~h}$ of salt stress, VL27 Vernal leaf after $27 \mathrm{~h}$ of salt stress, HRO Halo root control, VRO Vernal root control, HR3 Halo root after $3 \mathrm{~h}$ of salt stress, VR3 Vernal root after $3 \mathrm{~h}$ of salt stress, HR27 Halo root after $27 \mathrm{~h}$ of salt stress, VR27 Vernal root after $27 \mathrm{~h}$ of salt stress

consistently expressed under short-term and long-term salt stress in the salt tolerant cultivar. Fourth, this study found 74,705 SNPs which are valuable marker for future alfalfa breeding for salt tolerance. Fifth, we found 'Halo' under salt stress maintained 5 five times more DEGs in the root than 'Vernal'. Finally, this study found seven candidate genes for salt tolerance (MS.gene32989, MS.gene065734, MS.gene24746, MS.gene81767, MS.gene044457, MS.gene049840, and MS.gene46459) with unknown functions, suggesting a need for further research to understand their role in salt tolerance.

Due to polyploidy and its out-crossing nature, alfalfa has encountered many challenges in genomic studies [26] as compared to self-pollinated crops such as wheat
[27] and soybean (Glycine max) [28]. Thus, this transcriptomic study had considered several factors to overcome certain technical difficulties. First, identical clones were sampled at different time points from different alfalfa tissues. Unlike previous alfalfa transcriptomic studies, two technical replicates for each treatment were included to minimize technical errors. Furthermore, this study focused on both leaf and root tissues of alfalfa cultivars to capture tissue specific gene expression. These considerations seemed to be effective in capturing about 381 million high quality reads, which likely represents most of the genome of $M$. sativa. The raw reads showed a high percentage of mapping with the reference genome. These outputs should have enhanced our detection 
Table 3 List of 13 salt responsive candidate genes simultaneously highly expressed in both leaf and root tissues of salt tolerant alfalfa cultivar 'Halo'

\begin{tabular}{|c|c|c|c|c|c|c|c|c|}
\hline \multirow[t]{2}{*}{ Gene ID } & \multirow[t]{2}{*}{$\mathrm{Nr}$ ID $^{\mathrm{a}}$} & \multicolumn{3}{|c|}{$\log _{2} \mathrm{FC}^{\mathrm{b}}($ Leaf $)$} & \multicolumn{3}{|c|}{$\log _{2} F C$ (Root) } & \multirow[t]{2}{*}{ Putative function } \\
\hline & & Oh & $3 \mathrm{~h}$ & $27 \mathrm{~h}$ & Oh & $3 \mathrm{~h}$ & $27 \mathrm{~h}$ & \\
\hline MS.gene01091 & XP_003593572.2 & 6.7 & 7.3 & 6.9 & 8.4 & 9.4 & 10.3 & $\begin{array}{l}\text { T-complex protein } 1 \text { subunit gamma [Medicago truncatula } \\
\text { (barrel medic)] }\end{array}$ \\
\hline MS.gene013211 & XP_003602730.1 & 7.3 & 5.9 & 6.7 & 9.9 & 8.9 & 7.5 & ribonuclease TUDOR 1 [Medicago truncatula (barrel medic)] \\
\hline MS.gene013222 & XP_003602710.1 & 5.5 & 5.9 & 5.5 & 7.6 & 6.7 & 7.3 & $\begin{array}{l}\text { cleft lip and palate transmembrane protein } 1 \text { homolog } \\
\text { [Medicago truncatula (barrel medic)] }\end{array}$ \\
\hline MS.gene017955 & XP_003625216.1 & 5.5 & 6.9 & 5.6 & NA & 9.5 & 7.7 & $\begin{array}{l}40 S \text { ribosomal protein S20-2 [Medicago truncatula (barrel } \\
\text { medic)] }\end{array}$ \\
\hline MS.gene029200 & PNY01153.1 & 8.3 & 7.5 & 7.5 & 7.4 & 6.3 & 7.7 & replication factor A protein [Trifolium pratense] \\
\hline MS.gene029202 & XP_013470381.1 & 7.7 & 8.1 & 7.2 & 8.2 & 8.1 & 8.5 & $\begin{array}{l}\text { E3 ubiquitin-protein ligase CIP8 [Medicago truncatula (barrel } \\
\text { medic)] }\end{array}$ \\
\hline MS.gene029203 & XP_013470380.1 & NA & 6.8 & 7.3 & 6.8 & 8.0 & 8.5 & $\begin{array}{l}\text { F-box/LRR-repeat protein } 4 \text { [Medicago truncatula (barrel } \\
\text { medic)] }\end{array}$ \\
\hline MS.gene049294 & XP_003602595.1 & 4.0 & 4.1 & 5.3 & 6.3 & 5.4 & 4.3 & $\begin{array}{l}\text { caffeic acid 3-O-methyltransferase [Medicago truncatula (barrel } \\
\text { medic)] }\end{array}$ \\
\hline MS.gene32989 & GAU34467.1 & NA & 6.8 & 6.4 & 7.0 & 7.1 & 7.6 & hypothetical protein TSUD_06780 [Trifolium subterraneum] \\
\hline MS.gene 36780 & KEH43749.1 & 9.4 & 8.4 & 8.8 & 10.4 & 11.3 & 8.2 & elongation factor 1-alpha [Medicago truncatula (barrel medic)] \\
\hline MS.gene 36960 & AET01475.1 & 8.6 & 8.5 & 8.8 & 9.8 & 9.8 & 8.8 & elongation factor 1-alpha [Medicago truncatula] \\
\hline MS.gene52595 & XP_003624202.1 & 7.3 & 8.0 & 7.7 & 9.5 & 8.1 & 7.9 & $\begin{array}{l}\text { ER membrane protein complex subunit } 10 \text { [Medicago truncatula } \\
\text { (barrel medic)] }\end{array}$ \\
\hline MS.gene93979 & XP_003619874.1 & 7.7 & 6.9 & 7.9 & 7.4 & 7.4 & 7.0 & $\begin{array}{l}\text { NF-X1-type zinc finger protein NFXL1 [Medicago truncatula } \\
\text { (barrel medic)] }\end{array}$ \\
\hline
\end{tabular}

${ }^{a} \mathrm{Nr}$ ID is the protein accession number in NCBI non redundant protein database

${ }^{\mathrm{b}} \log 2 \mathrm{FC}$ stands for log Fold Change, where it is log base 2

of DEGs. For example, both alfalfa cultivars showed a similar trend in the number of DEGs in leaf tissue with the increase of salt exposure time. In this study, we also selected three different time points $(0 \mathrm{~h}, 3 \mathrm{~h}$, and $27 \mathrm{~h})$ to capture gene activation under short- and long- term salt stress. It has been established that salt responsive defense response is activated within $24 \mathrm{~h}$ of stress [29].

One of the main differences between the two cultivars was the number of DEGs in roots. In the root of salt tolerant alfalfa, the number of DEGs was similar between 3 $\mathrm{h}$ and $27 \mathrm{~h}$ of salt stress, but a sharp decrease was observed between $3 \mathrm{~h}$ and $27 \mathrm{~h}$ in the intolerant cultivar 'Vernal'. We speculate that such earlier activation of salt responsive genes and maintenance of a large number of DEGs might be a key characteristic for salt tolerance in alfalfa, suggesting alfalfa tolerance is associated with upregulation of key genes from short term salt stress. About $60 \%$ of DEGs were assigned to GO categories, while KEGG pathways for less than 30\% DEGs were identified in this study. The DEGs were mainly involved in metabolic pathways as revealed by KEGG pathway analysis. Although certain pathways involved in salt tolerance may be conserved in plant species such as in halophytes, there was still variation among plant species, cultivars, and tissues [5]. This study demonstrated that transcriptional variation in adaptation to salt stress exists not only among the alfalfa cultivars but also between the different tissues. 'Ion binding' (GO:0043167) was significantly enriched in both leaf and root tissues of 'Halo', but not in 'Vernal' under salt stress. This suggested that the genes responsible for 'ion binding' should be unique for salt tolerance of 'Halo' alfalfa. Therefore, the tissueand genotype-specific salt responsive genes might be useful in identification of salt tolerant genotypes in the future.

Among 13 candidate genes expressed in leaf and root tissues of 'Halo' under salt stress (Table 3) in this study, two genes (MS.gene013222 and MS.gene52595) are responsible for transmembrane protein function. These transmembrane proteins control gateways and selective transport of salt ions to facilitate salt tolerance in plants. Likewise, MS.gene013211, a homologous gene to ribonuclease TUDOR1, is involved in stress adaptation and highly expressed in leaf and root tissues of 'Halo' in our study [30]. MS.gene93979, a homologous gene to NF-X1-type zinc finger protein, is part of mechanisms that regulate growth under salt stress and was highly expressed in leaf and root tissues of 'Halo' in our study [31]. In addition, MS.gene029202 (E3 ubiquitin-protein ligase CIP8), MS.gene029203 (F-box/ LRR-repeat protein 4), MS.gene36780 and MS.gene36960 (elongation factor 1-alpha) were highly 
Table 4 List of 15 salt responsive candidate genes highly expressed in leaf tissue of salt tolerant alfalfa cultivar 'Halo'

\begin{tabular}{|c|c|c|c|c|c|}
\hline \multirow[t]{2}{*}{ Gene ID } & \multirow[t]{2}{*}{$\mathrm{Nr} I D^{a}$} & \multicolumn{3}{|c|}{$\log _{2} \mathrm{FC}^{\mathrm{b}}$ (Leaf) } & \multirow[t]{2}{*}{ Putative function } \\
\hline & & Oh & $3 \mathrm{~h}$ & $27 \mathrm{~h}$ & \\
\hline MS.gene024018 & KHN29288.1 & NA & 8.9 & 4.9 & Monothiol glutaredoxin-S14, chloroplastic [Glycine soja] \\
\hline MS.gene029055 & AFK45194.1 & 5.2 & 7.3 & 5.8 & $\begin{array}{l}\text { CDP-diacylglycerol--glycerol-3-phosphate 3-phosphatidyltransferase } \\
2 \text { [Medicago truncatula (barrel medic)] }\end{array}$ \\
\hline MS.gene029201 & AET03044.2 & NA & 7.5 & 9.0 & $\begin{array}{l}\text { replication protein } \mathrm{A} 70 \mathrm{kDa} \text { DNA-binding subunit C [Medicago } t \\
\text { runcatula (barrel medic)] }\end{array}$ \\
\hline MS.gene029206 & XP_024628388.1 & NA & 4.7 & 5.0 & FAD synthetase 1, chloroplastic [Medicago truncatula (barrel medic)] \\
\hline MS.gene037960 & XP_003589866.2 & NA & 2.7 & 2.7 & nuclear pore complex protein NUP1 [Medicago truncatula (barrel medic)] \\
\hline MS.gene038586 & RHN67456.1 & NA & 6.5 & 6.2 & putative minus-end-directed kinesin ATPase [Medicago truncatula] \\
\hline MS.gene065734 & XP_013467963.1 & 6.4 & 9.8 & 6.9 & uncharacterized LOC25483798 [Medicago truncatula (barrel medic)] \\
\hline MS.gene07287 & XP_003591401.1 & 8.8 & 11.2 & 10.5 & $\begin{array}{l}\text { calvin cycle protein CP12-2, chloroplastic [Medicago truncatula (barrel } \\
\text { medic)] }\end{array}$ \\
\hline MS.gene24098 & PNY14915.1 & 5.1 & 5.7 & 6.2 & thioredoxin-like protein CDSP32 chloroplastic-like [Trifolium pratense] \\
\hline MS.gene24746 & RHN68722.1 & 6.5 & 4.9 & 5.3 & hypothetical protein MtrunA17_Chr3g01 16951[Medicago truncatula] \\
\hline MS.gene36621 & XP_003627058.1 & NA & 4.7 & 4.5 & stem 28 kDa glycoprotein [Medicago truncatula (barrel medic)] \\
\hline MS.gene39381 & RHN38725.1 & NA & 6.6 & 6.5 & putative nucleoporin protein Ndc1-Nup [Medicago truncatula] \\
\hline MS.gene63155 & RHN41150.1 & NA & 7.3 & 4.2 & putative protein kinase RLK-Pelle-LRR-XII-1 family [Medicago truncatula] \\
\hline MS.gene81767 & XP_013467963.1 & NA & 4.8 & 3.6 & uncharacterized LOC25483798 [Medicago truncatula (barrel medic)] \\
\hline MS.gene99197 & AlP98334.1 & 4.6 & 4.8 & 4.7 & ZEP [Medicago sativa] \\
\hline
\end{tabular}

${ }^{a} \mathrm{Nr}$ ID is the protein accession number in NCBI non redundant protein database

${ }^{\mathrm{b}} \log 2 \mathrm{FC}$ stands for log Fold Change, where it is log base 2

expressed in leaf and root tissues of salt tolerant alfalfa in our study. These genes are involved in regulation of a number of biological processes including biotic and abiotic stress tolerances [32-34]. For example, MS.gene049294, which is a homologous gene of Omethyltransferase, was found to improve salt tolerance in transgenic Arabidopsis [35]. MS.gene01091, a homologous gene to the T-complex protein 1 subunit gamma, showed high expression in both root and leaf tissue and is involved in intracellular assembly and folding of various proteins [36]. MS.gene029200, a homologous gene to replication factor A protein, was highly expressed in both leaf and root tissues of 'Halo' in our study, which might play a role in binding, replication, repair, and recombination of DNA under stress conditions [37].

In this study, we found 15 and 18 candidate genes specific to leaf and root tissues of salt tolerance 'Halo' alfalfa (Tables 4, 5). In leaf tissue, nine genes showed consistent expression under salt stress, while six of them were expressed at all three time points. In our study, salt tolerant alfalfa showed an increased expression of MS.gene024018 and MS.gene24098 with putative functions of chloroplastic glutaredoxin and thioredoxin-like protein CDSP32, respectively. The two genes (MS.gene024018, MS.gene24098) were found to be important for defense against protein oxidative damage in other studies [38, 39]. This is important because salt stress results in the formation of reactive oxygen species, which damage protein, membrane lipids, and nucleic acids [40]. MS.gene63155, a homologous gene to receptor-like kinases (RLKs), are a family of transmembrane proteins, showed lowered expression with time under salt stress. This gene is involved in plant growth as well as stress response [41]. Two nucleoporin proteins (MS.gene037960 and MS.gene39381) were expressed consistently under salt stress in leaf tissue of 'Halo'. These proteins connect cytoplasm and nucleoplasm, and are involved in abiotic stress tolerance [42]. MS.gene038586 is a homologous gene to kinesin super family proteins which plays a significant role in intracellular transport and are critical for cellular functioning and survival [43]. MS.gene029206, a homologous gene to FAD synthetase 1 , is a co-factor for various enzymes that participate in numerous metabolic processes like photosynthesis, electron transport, fatty acid oxidation and biosynthesis of secondary metabolites [44]. MS.gene36621, a homologous gene to stem $28 \mathrm{kDa}$ glycoprotein, which is known as a vegetative storage protein, was highly expressed under salt stress in our study. This protein plays a certain role as a somatic storage protein during early seedling development [45]. Salt tolerant alfalfa showed a high expression of MS.gene07287 in leaf, a homologous gene to calvin cycle protein CP122. This gene is involved in photosynthesis and improved plant growth [46]. The Calvin-Benson cycle is the 
Table 5 List of 18 salt responsive candidate genes highly expressed in root tissue of salt tolerant alfalfa cultivar 'Halo'

\begin{tabular}{|c|c|c|c|c|c|}
\hline \multirow[t]{2}{*}{ Gene ID } & \multirow[t]{2}{*}{$\mathrm{Nr} I D^{a}$} & \multicolumn{3}{|c|}{$\log _{2} \mathrm{FC}^{\mathrm{b}}$ (Root) } & \multirow[t]{2}{*}{ Putative function } \\
\hline & & $\mathrm{Oh}$ & $3 \mathrm{~h}$ & $27 \mathrm{~h}$ & \\
\hline MS.gene002389 & XP_003593475.1 & 7.4 & 8.0 & 7.9 & secretory carrier-associated membrane protein [Medicago truncatula (barrel medic)] \\
\hline MS.gene011517 & XP_003608741.1 & 8.1 & 8.6 & 8.6 & 14 kDa proline-rich protein DC2.15 [Medicago truncatula (barrel medic)] \\
\hline MS.gene013923 & XP_003624859.1 & 6.5 & 6.6 & 6.6 & $\begin{array}{l}\text { histone-lysine N-methyltransferase, H3 lysine-9 specific SUVH1 [Medicago truncatula } \\
\text { (barrel medic)] }\end{array}$ \\
\hline MS.gene023013 & XP_013448530.1 & 8.0 & 6.0 & 6.2 & peptidyl-prolyl cis-trans isomerase FKBP62 [Medicago truncatula (barrel medic)] \\
\hline MS.gene02427 & AFK40071.1 & 6.9 & 5.7 & 5.5 & soluble inorganic pyrophosphatase PPA1 [Medicago truncatula (barrel medic)] \\
\hline MS.gene029223 & XP_003592714.1 & 5.9 & 6.7 & 6.1 & E3 ubiquitin ligase BIG BROTHER-related [Medicago truncatula (barrel medic)] \\
\hline MS.gene044457 & XP_013458006.1 & 7.3 & 6.4 & 7.0 & uncharacterized LOC25493896 [Medicago truncatula (barrel medic)] \\
\hline MS.gene049130 & RDX70942.1 & 9.2 & 10.0 & 8.5 & Aldehyde dehydrogenase family 2 member C4, partial [Mucuna pruriens] \\
\hline MS.gene049840 & XP_024638826.1 & 7.4 & 7.2 & 8.1 & uncharacterized LOC11406476 [Medicago truncatula (barrel medic)] \\
\hline MS.gene056386 & XP_013456308.1 & 8.2 & 8.3 & 6.7 & fructokinase-2 [Medicago truncatula (barrel medic)] \\
\hline MS.gene058673 & PNX87529.1 & 7.9 & 5.5 & 9.5 & heavy-metal-associated domain-containing protein [Trifolium pratense] \\
\hline MS.gene070486 & XP_003616935.1 & 5.7 & 5.5 & 7.9 & $\begin{array}{l}\text { phosphatidylglycerol/phosphatidylinositol transfer protein [Medicago truncatula (barrel } \\
\text { medic)] }\end{array}$ \\
\hline MS.gene073760 & XP_013468212.1 & 7.1 & 7.8 & 6.9 & probable E3 ubiquitin-protein ligase LOG2 [Medicago truncatula (barrel medic)] \\
\hline MS.gene43277 & XP_003608928.1 & 6.9 & 7.7 & 7.4 & betaine aldehyde dehydrogenase 1, chloroplastic [Medicago truncatula (barrel medic)] \\
\hline MS.gene46459 & XP_013467706.1 & 8.6 & 9.5 & 7.7 & uncharacterized LOC25483559 [Medicago truncatula (barrel medic)] \\
\hline MS.gene61130 & XP_004487038.1 & NA & 4.4 & 4.1 & 605 ribosomal protein L23a-2-like [ Cicer arietinum (chickpea)] \\
\hline MS.gene67829 & XP_013454067.1 & 9.5 & 8.7 & 9.1 & $\begin{array}{l}\text { ribosomal RNA small subunit methyltransferase nep-1 [Medicago truncatula (barrel } \\
\text { medic)] }\end{array}$ \\
\hline MS.gene95536 & XP_013469288.1 & 6.7 & 7.4 & 7.0 & acyl-CoA-binding domain-containing protein 6 [Medicago truncatula (barrel medic)] \\
\hline
\end{tabular}

${ }^{a} \mathrm{Nr}$ ID is the protein accession number in NCBI non redundant protein database

${ }^{\mathrm{b}} \log 2 \mathrm{FC}$ stands for log Fold Change, where it is log base 2

primary pathway of carbon fixation, producing carbon compounds. CP12 facilitates the formation of a complex between glyceraldehyde-3-phosphate dehydrogenase and phosphoribulokinase, thereby increasing the photosynthetic capacity of the plant [46]. MS.gene99197, a homologous gene to zeaxanthin epoxidase (ZEP), was highly expressed at all three time points in leaf tissue of 'Halo'. It is an important enzyme in ABA biosynthesis and plays an important role in osmotic tolerance [47].

In root tissue, one (MS.gene61130) of the 18 genes detected was consistently expressed under salt stress, while the rest were expressed at all three time points in our study (Table 5). MS.gene002389, a homologous gene to secretory carrier-associated membrane proteins, is involved in membrane trafficking and found to influence accumulation of secondary cell wall components in Poplus [48]. MS.gene011517, a homologous gene to 14$\mathrm{kDa}$ proline-rich protein DC2.15, is involved in cell wall modification and organization [49]. The plant cell wall is not only a physical barrier between the plant and the environment but also is a responsive part of the plant to biotic and abiotic stresses. The finding of tissue specific salt tolerant candidate genes responsible for the plant cell wall is promising and underlines the need for further research on its role in response to salt stress. In addition, salt stress causes lipid peroxidation, resulting in damage of membrane lipids and eventual cell leakage. This study showed salt tolerant alfalfa had an increased expression of MS.gene049130, a homologous gene to aldehyde dehydrogenase, responsible for oxidation of aldehydes produced during lipid peroxidation thereby detoxifying cells [50]. MS.gene95536 is a homologous gene to acyl-CoAbinding domain-containing protein 6 , which is associated with phospholipid metabolism. This gene also was shown to play a role in the freezing tolerance of Arabidopsis [51]. MS.gene070486, a homologous gene to phosphatidylinositol transfer proteins, plays an important role in signal transduction and facilitates lipid transfer between membranes [52]. MS.gene056386, a homologous gene to fructokinases, are important enzymes catalyzing fructose phosphorylation and are involved in plant growth and development [53]. MS.gene058673, a homologous gene to heavy-metalassociated domain-containing protein conferring tolerance to abiotic stress [54]. MS.gene073760, a homologous gene to probable E3 ubiquitin-protein ligase LOG2, which induces amino acid secretion. This is the main form of organic nitrogen in the plant [55]. MS.gene02427, a homologous gene to soluble inorganic pyrophosphatase, is tightly linked with carbohydrate 


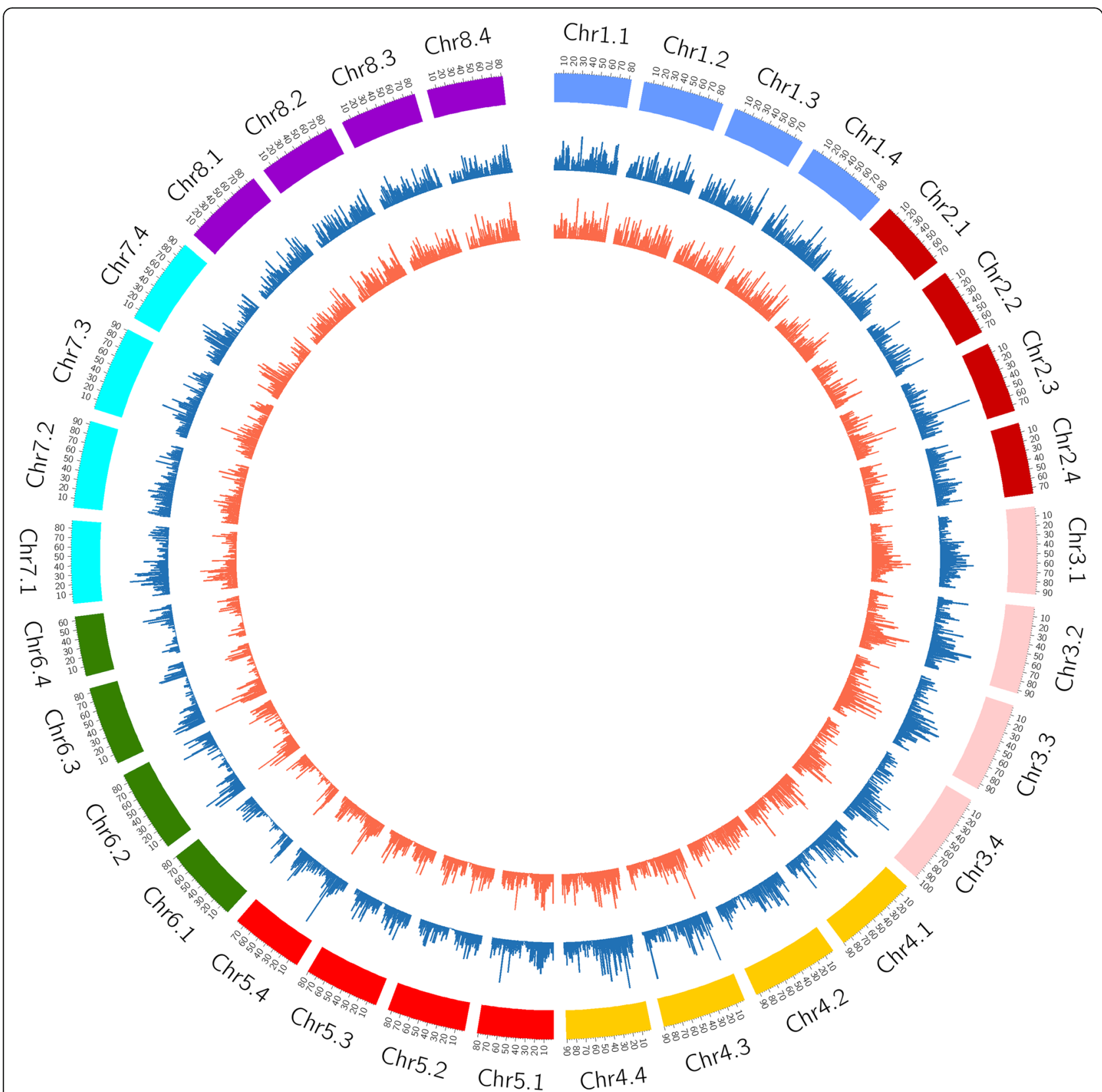

Fig. 5 Distribution of SNPs identified over 32 allelic chromosomes of alfalfa (Medicago sativa L.) is represented with the Circos diagram. Histogram (1-70) showing distribution of SNPs per Mb bins across genome of alfalfa. The 8 alfalfa chromosomes (Chr1-8) are shown on outermost circle, middle (blue) and innermost (orange) circles represent SNPs distribution of salt intolerant 'Vernal' and salt tolerant 'Halo' alfalfa

metabolism. It plays an important role in stress adaptive responses [56]. Carbohydrate metabolism produces soluble carbohydrates that are important for salt tolerance because of its osmotic adjustment function in the root.

\section{Conclusion}

Our study generated a unique set of DEGs for alfalfa salt tolerance studies and breeding efforts. The information is useful for better understanding of temporal expression of genes in response to salt stress. Furthermore, GO annotation and KEGG pathway analysis of the DEGs provided insights to the different molecular and biological processes between salt tolerant and intolerant alfalfa cultivars. In particular, 'ion binding activity' was found as a key molecular activity specific to salt tolerant alfalfa cultivar 'Halo'. Based on this finding, salt tolerance in alfalfa appears to be associated with consistent expression of genes for selective transport of salt ions and compounds, increasing 
photosynthetic capacity as well as carbohydrate metabolism, enhancing defense against oxidative damage, modification of root cell wall and protection against lipid peroxidation. The SNPs discovered in this study will be valuable for molecular marker-assisted breeding for the development of salt tolerant alfalfa.

\section{Methods}

\section{Plant material and salt treatment}

Two alfalfa cultivars, 'Halo' (obtained from Agriculture and Agri-Food Canada, Swift Current Research and Development Centre) and 'Vernal' (sourced from Dr. Biligetu's lab, Crop Development Centre, University of Saskatchewan) were chosen for the study. Cultivar 'Halo' was selected for improved salinity tolerance for germination, seedling growth, and mature plant regrowth at $100 \mathrm{mM} \mathrm{NaCl}$ in the greenhouse conditions [57], and cultivar 'Vernal' was considered as a salinity intolerant cultivar [58, 59]. Four genotypes (biological replicates) of each cultivar were grown from seeds in the College of Agriculture and Bioresources greenhouse at the University of Saskatchewan (45 Innovation Blvd., Saskatoon, SK) for 12 weeks. Six identical clones of each biological replicate were produced by stem cuttings. Salt stress of $120 \mathrm{mM} \mathrm{NaCl}$ approximately corresponding to $12 \mathrm{dS}$ $\mathrm{m}^{-1}$ electrical conductivity was applied on 4 week old seedlings. Salt stress of $12 \mathrm{dS} \mathrm{m}^{-1}$ was selected from our earlier greenhouse study where alfalfa was grown at various gradients of salt stress and alfalfa cultivars showed variation in response to salt stress at $12 \mathrm{dS} \mathrm{m}^{-1}$, with increase in salt stress from $12 \mathrm{dS} \mathrm{m}^{-1}$ all alfalfa cultivars showed very high mortality (Bhattarai et al., unpublished). Leaf and root samples were collected immediately before salt treatment (control, $0 \mathrm{~h}$ ), and at $3 \mathrm{~h}$ and $27 \mathrm{~h}$ of salt treatments. The samples were immediately frozen in liquid nitrogen and then stored at $-80^{\circ} \mathrm{C}$ for 2 weeks until total RNA extraction carried out.

\section{Tissue sample and RNA isolation}

About $100 \mathrm{mg}$ of tissue samples were disrupted using TissueLyser II and total RNA was extracted with RLT buffer using the Qiagen RNeasy Plant Mini Kit (Qiagen Inc., Mississauga, ON, Canada) according to the manufacturer's protocol. DNase treatment was performed using the Ambion DNA-free DNase treatment and removal reagents (Life Technologies, Carlsbad, CA, USA) to remove contaminant genomic DNA from the isolated total RNA. Nanodrop 2000 (Thermo Fisher Scientific, Wilmington, DE, USA) was used to measure the total RNA concentration. RNA integrity number was evaluated for 12 samples using RNA 6000 Nano labchip on 2100 Agilent Bioanalyzer (Agilent Technologies, Waldbronn, Germany) (Additional file 1: Table S3; Additional file 2: Fig. S1).

\section{Library preparation and sequencing}

Poly (A) RNA was purified from total RNA using Magnosphere MS150 OligodT beads according to the manufacturer's protocol. The RNA samples were subsequently used in cDNA library preparation. Two cDNA libraries were prepared using Lexogen's SENSE mRNA-Seq Library Prep Kit V2 (Lexogen, Vienna, Austria). To minimize technical errors, two technical replicates of each treatment were divided into two cDNA libraries. The technical replicates represented two clones of the same genotype (biological replicate) by separately extracting RNA. Thus, 96 samples $(2$ cultivars $\times 2$ tissue types $\times 3$ time points $\times 4$ biological replicates $\times 2$ technical replicates) were collected for the study. The cDNA libraries were sequenced using the Illumina HiSeq v4 system at the National Research Council of Canada, Saskatoon, Canada. Raw reads were deposited in the National Center for Biotechnology Information (NCBI) and received BioProject ID PRJNA657410.

\section{Reference-based mapping, differential gene expression analysis and annotation}

The quality of the raw sequence was assessed using the FastQC software [60]. The raw reads were cleaned by removing adapters and low-quality sequences using Trimmomatic v.0.36 based on the default setting of pairedend mode, phred 33 and threads 6 [61]. The trimmed high-quality reads of samples from the two technical replicates were merged and mapped with the alfalfa reference genome (https://doi.org/10.6084/m9.figshare. 12327602.v3) [62, 63] using STAR (v2.6.1a) [64] with "quantMode" as "GeneCounts". The obtained "ReadsPerGene" of each sample were extracted as count matrix and the differentially expressed genes were analyzed using DeSeq2 package [65] where data were normalized by the median of the ratios. The threshold of padj < 0.001 and the Log fold change $(\log 2 \mathrm{FC})>2$ were used to determine the significance of gene expression differences. The functional annotation of the DEGs were also extracted via searches of NR databases as available in "query.blastp.db.out" and gene ontologies were obtained via searches of the GO databases as available in "Msa.GO.list.up" likewise Kyoto Encyclopedia of Genes and Genomes (KEGG) Ortholog (KO) were obtained via search of KO databases as available in "query.ko" from Zeng [63]. Gene ontology analysis of the DEGs was done for biological process, cellular components, and molecular function by AgriGO v2.0 software [66]. Venn diagrams were produced using the Venny tool [67].

\section{Identification of single nucleotide polymorphisms (SNPs)}

SNPs calling was done using freebayes software using the bam file generated in the mapping process where at least 5 supporting observations were required to be 
consider a variant [68]. To visualize the relative distribution of SNPs over chromosomes, Circos tool was used [69].

\section{Abbreviations}

ABA: Abscisic acid; AVP1: Arabidopsis type I proton-pumping pyrophosphatase; DEGs: Differentially expressed genes; $\mathrm{dS}^{-1}$ : DeciSiemens per metre; DREB: Dehydration-responsive element binding protein; $\mathrm{NHX}: \mathrm{Na}^{+} / \mathrm{H}^{+}$ antiporter; CBRLK: Calcium/calmodulin-binding receptor-like kinase; ZFP: Zinc finger protein; APX: Ascorbate peroxidase; NDPK2: Nucleoside diphosphate kinase 2; codA: Choline oxidase; RLK: Receptor-like kinase; FAD: Flavin adenine dinucleotide; ZEP: Zeaxanthin epoxidase

\section{Supplementary Information}

The online version contains supplementary material available at https://doi. org/10.1186/s12870-021-03201-4.

Additional file 1 : Table S1. List of 237 differentially expressed genes in leaf tissue at the control $(0 \mathrm{~h}), 3 \mathrm{~h}$, and $27 \mathrm{~h}$ of salt stress between salt tolerant 'Halo' and salt intolerant 'Vernal' cultivars of alfalfa. Table S2. List of 295 differentially expressed genes in root tissue at the control $(0 \mathrm{~h}), 3$ $\mathrm{h}$, and $27 \mathrm{~h}$ of salt stress between salt tolerant 'Halo' and salt intolerant Vernal' cultivars of alfalfa. Table S3. RNA quality of 12 RNA samples determined with 2100 Agilent Bioanalyzer.

Additional file 2 : Fig. S1. Electropherogram of 12 RNA samples.

\section{Acknowledgements}

We would like to thank Carolee Horbach, and Gregory Peterson at the Saskatoon Research and Development Centre, Agriculture and Agri-Food Canada, Saskatoon, SK, for their technical assistance in RNA extraction and library preparation and Fangqin Zeng and Raju Chaudhary for their help and suggestions during data analysis. This research was enabled in part by support provided by WestGrid and Compute Canada. We would also like to thank greenhouse staff at the College of Agriculture and Bioresources, University of Saskatchewan, for their support and assistance.

\section{Authors' contributions}

B.B. conceived the project; S.B., B.B. designed experiments; K.T. provided guidance on the salt stress system; B.B. prepared the study materials; S.B. performed experiments; S.B., Y.-B.F., B.B. analyzed data; S.B. wrote a first version of the manuscript and Y.-B.F., B.C., B.B., C.K., K.T. substantially contributed to the last version of the manuscript. All authors read and approved the final manuscript.

\section{Funding}

The research was funded by an NSERC Discovery grant.

\section{Availability of data and materials}

Raw reads have been deposited in the National Center for Biotechnology Information (NCBI) and received BioProject ID PRJNA657410. The data will be accessible with the following link: "https://www.ncbi.nlm.nih.gov/bioproject/ PRJNA657410".

\section{Declarations}

\section{Ethics approval and consent to participate}

Not applicable.

\section{Consent for publication}

Not applicable.

\section{Competing interests}

The authors declare that they have no competing interests.

\section{Author details}

'Department of Plant Sciences, College of Agriculture and Bioresources, University of Saskatchewan, 51 Campus Drive, Saskatoon, SK S7N 5A8, Canada. ${ }^{2}$ Plant Gene Resources of Canada, Saskatoon Research and
Development Centre, Agriculture and Agri-Food Canada, 107 Science Place, Saskatoon, SK S7N 0X2, Canada. ${ }^{3}$ Canadian Light Source, 44 Innovation Boulevard, Saskatoon, SK S7N 2V3, Canada.

Received: 18 March 2021 Accepted: 31 August 2021

Published online: 05 October 2021

\section{References}

1. Blondon F, Marie D, Brown S, Kondorosi A. Genome size and base composition in Medicago siativa and M. truncatula species. Genome. 1994; 37(2):264-70. https://doi.org/10.1139/g94-037.

2. Maas EV, Hoffman GJ. Crop salt tolerance-current assessment. J Irrig Drain Div. 1977;103(2):115-34. https://doi.org/10.1061/JRCEA4.0001137.

3. Johnson DW, Smith SE, Dobrenz AK. Selection for increased forage yield in alfalfa at different $\mathrm{NaCl}$ levels. Euphytica. 1992;60(1):27-35. https://doi.org/1 $0.1007 / \mathrm{BF} 00022255$.

4. Gregorio GB, Senadhira D. Genetic analysis of salinity tolerance in rice (Oryza sativa L.). Theoret Appl Genet. 1993;86:333-8.

5. Munns R, Tester M. Mechanisms of salinity tolerance. Annu Rev Plant Biol. 2008:59(1):651-81. https://doi.org/10.1146/annurev.arplant.59.032607.092911.

6. Postnikova OA, Shao J, Nemchinov LG. Analysis of the alfalfa root transcriptome in response to salinity stress. Plant Cell Physiol. 2013;54(7): 1041-55. https://doi.org/10.1093/pcp/pct056.

7. Luo D, Zhou Q, Wu YG, Chai XT, Liu WX, Wang YR, et al. Full length transcript sequencing and comparative transcriptomic analysis to evaluate the contribution of osmotic and ionic stress components towards salinity tolerance in the roots of cultivated alfalfa (Medicago sativa L.). BMC Plant Biol. 2019;19:32.

8. Lei Y, Xu Y, Hettenhausen C, Lu C, Shen G, Zhang C, et al. Comparative analysis of alfalfa (Medicago sativa L.) leaf transcriptomes reveals genotypespecific salt tolerance mechanisms. BMC Plant Biol. 2018;18(1):35. https://doi. org/10.1186/s12870-018-1250-4.

9. Gruber M, Xia J, Yu M, Steppuhn H, Wall K, Messer D, et al. Transcript analysis in two alfalfa salt tolerance selected breeding populations relative to a non-tolerant population. Genome. 2017;60(2):104-27. https://doi.org/1 0.1139/gen-2016-0111.

10. Winicov I. Alfin 1 transcription factor overexpression enhances plant root growth under normal and saline conditions and improves salt tolerance in alfalfa. Planta. 2000;210(3):416-22. https://doi.org/10.1007/PL00008150.

11. Bao AK, Wang SM, Wu GQ, Xi JJ, Zhang JL, Wang CM. Overexpression of the Arabidopsis H+-PPase enhanced resistance to salt and drought stress in transgenic alfalfa (Medicago sativa L.). Plant Sci. 2009;176:232-40.

12. Jin T, Chang Q, Li W, Yin D, Li Z, Wang D, et al. Stress-inducible expression of GMDREB1 conferred salt tolerance in transgenic alfalfa. Plant Cell Tissue Organ Cult. 2010;100(2):219-27. https://doi.org/10.1007/s11240-009-9628-5.

13. Li W, Wang D, Jin T, Chang Q, Yin D, Xu S, et al. The vacuolar Na+/H+ antiporter gene SsNHXIfrom the halophyte Salsola soda confers salt tolerance in transgenic alfalfa (Medicago sativa L.). Plant Mol Biol Rep. 2011; 29(2):278-90. https://doi.org/10.1007/s11105-010-0224-y.

14. Zhang YM, Liu ZH, Wen ZY, Zhang HM, Yang F, Guo XL. The vacuolar Na+/ $\mathrm{H}+$ antiport gene TaNHX2 confers salt tolerance on transgenic alfalfa (Medicago sativa L.). Funct Plant Biol. 2012;39(8):708-16. https://doi.org/10.1 071/FP12095

15. Bai X, Liu J, Tang L, Cai H, Chen M, Ji W, et al. Overexpression of GSCBRLK from Glycine soja enhances tolerance to salt stress in transgenic alfalfa (Medicago sativa). Funct Plant Biol. 2013;40(10):1048-56. https://doi.org/10.1 071/FP12377.

16. Tang L, Cai H, Ji W, Luo X, Wang Z, Wu J, et al. Overexpression of GsZFP1enhances salt and drought tolerance in transgenic alfalfa (Medicago sativa L.). Plant Physiol Biochem. 2013;71:22-30. https://doi.org/10.1016/j.pla phy.2013.06.024

17. Zhang Q, Ma C, Xue X, Xu M, Li J, Wu JX. Overexpression of a cytosolic ascorbate peroxidase gene, OSAPX2, increases salt tolerance in transgenic alfalfa. J Integr Agric. 2014a;13(11):2500-7. https://doi.org/10.1016/S2095-311 9(13)60691-7.

18. Zhang LQ, Niu YD, Huridu H, Hao JF, Qi Z, Hasi A. Salicornia europaea L. $\mathrm{Na}+/ \mathrm{H}+$ antiporter gene improves salt tolerance in transgenic alfalfa (Medicago sativa L.). Genet Mol Res. 2014b;13(3):5350-60. https://doi.org/1 0.4238/2014.July.24.14.

19. Wang Z, Li H, Ke Q, Jeong JC, Lee HS, Xu B, et al. Transgenic alfalfa plants expressing AtNDPK2 exhibit increased growth and tolerance to abiotic 
stresses. Plant Physiol Biochem. 2014;84:67-77. https://doi.org/10.1016/j.pla phy.2014.08.025.

20. Li H, Wang Z, Ke Q, Ji CY, Jeong JC, Lee H, et al. Overexpression of codA gene confers enhanced tolerance to abiotic stresses in alfalfa. Plant Physiol Biochem. 2014;85:31-40. https://doi.org/10.1016/j.plaphy.2014.10.010.

21. Tang L, Cai H, Zhai H, Luo X, Wang Z, Cui L, et al. Overexpression of Glycine soja WRKY2O enhances both drought and salt tolerance in transgenic alfalfa (Medicago sativa L.). Plant Cell Tissue Organ Cult. 2014;118(1):77-86. https:// doi.org/10.1007/s11240-014-0463-y.

22. Ramagopal S. Salinity stress induced tissue-specific proteins in barley seedling. Plant Physiol. 1987a;84(2):324-31. https://doi.org/10.1104/pp. 84.2.324.

23. Ramagopal S. Differential mRNA transcription during salinity stress in barley. Proc Natl Acad Sci U S A. 1987b;84(1):94-8. https://doi.org/10.1073/pnas. 84.1.94.

24. Kumar S, Beena AS, Awana M, Singh A. Salt-induced tissue-specific cytosine methylation downregulates expression of HKT genes in contrasting wheat (Triticum aestivum L.) genotypes. DNA Cell Biol. 2017;36:283-94.

25. Villarino GH, Hu Q, Scanlon MJ, Mueller L, Bombarely A, Mattson NS. Dissecting tissue-specific transcriptomic responses from leaf and roots under salt stress in Petunia hybrida Mitchell. Genes. 2017:8(8):195. https://doi. org/10.3390/genes8080195

26. Liu Z, Chen T, Ma L, Zhao Z, Zhao PX, Nan Z, et al. Global transcriptome sequencing using the Illumina platform and the development of EST-SSR markers in autotetraploid alfalfa. PLoS One. 2013;8(12):e83549. https://doi. org/10.1371/journal.pone.0083549.

27. Feldman M, Levy AA. Allopolyploidy - a shaping force in the evolution of wheat genomes. Cytogenet Genome Res. 2005;109(1-3):250-8. https://doi. org/10.1159/000082407.

28. Gill N, Findley S, Walling JG, Hans C, Ma J, Doyle J, et al. Molecular and chromosomal evidence for allopolyploidy in soybean. Plant Physiol. 2009; 151(3):1167-74. https://doi.org/10.1104/pp.109.137935.

29. Hernandez JA, Almansa MS. Short-term effects of salt stress on antioxidant systems and leaf water relations of pea leaves. Physiol Plant. 2002;115(2): 251-7. https://doi.org/10.1034/j.1399-3054.2002.1150211.x.

30. Yan C, Yan Z, Wang Y, Yan X, Han Y. Tudor-SN, a component of stress granules, regulates growth under salt stress by modulating GA200x3 mRNA levels in Arabidopsis. J Exp Bot. 2014;65(20):5933-44. https://doi.org/10.1 093/jxb/eru334.

31. Lisso J, Altmann T, Müssig C. The AtNFXL1 gene encodes a NF-X1 type zinc finger protein required for growth under salt stress. FEBS Lett. 2006;580(20): 4851-6. https://doi.org/10.1016/j.febslet.2006.07.079.

32. Mazzucotelli E, Belloni S, Marone D, De Leonardis A, Guerra D, Di Fonzo N, et al. The e3 ubiquitin ligase gene family in plants: regulation by degradation. Curr Genomics. 2006;7(8):509-22. https://doi.org/10.2174/13892 0206779315728.

33. Song JB, Wang YX, Li HB, Li BW, Zhou ZS, Gao S, et al. The F-box family genes as key elements in response to salt, heavy metal and drought stresses in Medicago truncatula. Funct Integr Genomics. 2015;15(4):495-507. https://doi.org/10.1007/s10142-015-0438-z.

34. Gao Y, Ma J, Zheng JC, Chen J, Chen M, Zhou YB, et al. The elongation factor GmEF4 is involved in the response to drought and salt tolerance in soybean. Int J Mol Sci. 2019;20(12):3001. https://doi.org/10.3390/ijms20123001.

35. Niron $\mathrm{H}$, Türet $\mathrm{M}$. A putative common bean chalcone o-methyltransferase improves salt tolerance in transgenic Arabidopsis thaliana. J Plant Growth Regul. 2020;39(3):957-69. https://doi.org/10.1007/s00344-019-10040-z.

36. Bhaskar KN, Goyal N. Cloning, characterization and sub-cellular localization of gamma subunit of T-complex protein-1 (chaperonin) from Leishmania donovani. Biochem Biophys Res Commun. 2012;429:70-4.

37. Longhese MP, Plevani P, Lucchini $G$. Replication factor $A$ is required in vivo for DNA replication, repair, and recombination. Mol Cell Biol. 1994;14(12): 7884-90. https://doi.org/10.1128/mcb.14.12.7884-7890.1994.

38. Broin M, Rey P. Potato plants lacking the CDSP32 plastidic thioredoxin exhibit overoxidation of the BAS1 2-cysteine peroxiredoxin and increased lipid peroxidation in thylakoids under photooxidative stress. Plant Physiol. 2003;132(3):1335-43. https://doi.org/10.1104/pp.103.021626.

39. Cheng NH, Liu JZ, Brock A, Nelson RS, Hirschi KD. AtGRXcp, an Arabidopsis chloroplastic glutaredoxin, is critical for protection against protein oxidative damage. J Biol Chem. 2006;281(36):26280-8. https://doi.org/10.1074/jbc. M601354200.
40. Foyer $\mathrm{CH}$, Noctor G. Oxidant and antioxidant signaling in plants: a reevaluation of the concept of oxidative stress in a physiological context. Plant Cell Environ. 2005;28(8):1056-71. https://doi.org/10.1111/j.1365-3040.2 005.01327.x.

41. Shiu SH, Bleecker AB. Expansion of the receptor-like kinase/Pelle gene family and receptor-like proteins in Arabidopsis. Plant Physiol. 2003;132(2):530-43. https://doi.org/10.1104/pp.103.021964

42. Dong $\mathrm{CH}$, Hu X, Tang W, Zheng X, Kim YS, Lee BH, et al. A putative Arabidopsis nucleoporin, AtNUP160, is critical for RNA export and required for plant tolerance to cold stress. Mol Cell Biol. 2006;26:9533-43.

43. Hirokawa N, Noda Y. Intracellular transport and kinesin superfamily proteins, KIFs: structure, function, and dynamics. Physiol Rev. 2008;88(3):1089-118. https://doi.org/10.1152/physrev.00023.2007.

44. Sandoval FJ, Zhang Y, Roje S. Flavin nucleotide metabolism in plants: monofunctional enzymes synthesize fad in plastids. J Biol Chem. 2008; 283(45):30890-900. https://doi.org/10.1074/jbc.M803416200.

45. Mason HS, Guerrero FD, Boyer JS, Mullet JE. Proteins homologous to leaf glycoproteins are abundant in stems of dark-grown soybean seedlings. Analysis of proteins and cDNAs. Plant Mol Biol. 1988;11(6):845-56. https:// doi.org/10.1007/BF00019524.

46. López-Calcagno PE, Abuzaid AO, Lawson T, Raines CA. Arabidopsis CP12 mutants have reduced levels of phosphoribulokinase and impaired function of the Calvin-Benson cycle. J Exp Bot. 2017;68(9):2285-98. https://doi.org/1 0.1093/jxb/erx084.

47. Park HY, Seok HY, Park BK, Kim SH, Goh CH, Lee BH, et al. Overexpression of Arabidopsis ZEP enhances tolerance to osmotic stress. Biochem Biophys Res Commun. 2008;375(1):80-5. https://doi.org/10.1016/j.bbrc.2008.07.128.

48. Obudulu O, Mähler N, Skotare T, Bygdell J, Abreu IN, Ahnlund M, et al. A multi-omics approach reveals function of secretory carrier-associated membrane proteins in wood formation of Populus trees. BMC Genomics. 2018;19(1):11. https://doi.org/10.1186/s12864-017-4411-1.

49. Fan W, Lou HQ, Gong YL, Liu MY, Wang ZQ, Yang JL, et al. Identification of early Al-responsive genes in rice bean (Vigna umbellata) roots provides new clues to molecular mechanisms of Al toxicity and tolerance. Plant Cell Environ. 2014;37(7):1586-97. https://doi.org/10.1111/pce.12258.

50. Koncitikova R, Vigouroux A, Kopecna M, Andree T, Bartos J, Sebela M, et al. Role and structural characterization of plant aldehyde dehydrogenases from family 2 and family 7. Biochem J. 2015;468(1):109-23. https://doi.org/10.1 042/BJ20150009.

51. Chen QF, Xiao S, Chye ML. Arabidopsis ACBP6 is an acyl-CoA-binding protein associated with phospholipid metabolism. Plant Signal Behav. 2008; 3(11):1019-20. https://doi.org/10.4161/psb.6762.

52. Garner K, Hunt AN, Koster G, Somerharju P, Groves E, Li M, et al. Phosphatidylinositol transfer protein, cytoplasmic 1 (PITPNC1) binds and transfers phosphatidic acid. J Biol Chem. 2012;287(38):32263-76. https://doi. org/10.1074/jbc.M112.375840.

53. Stein O, Granot D. Plant Fructokinases: evolutionary, developmental, and metabolic aspects in sink tissues. Front Plant Sci. 2018;9:339. https://doi. org/10.3389/fpls.2018.00339.

54. Sun XH, Yu G, Li JT, Jia P, Zhang JC, Jia CG, et al. A heavy metal-associated protein (AcHMA1) from the halophyte, Atriplex canescens (Pursh) Nutt. confers tolerance to iron and other abiotic stresses when expressed in Saccharomyces cerevisiae. Int J Mol Sci. 2014;15(8):14891-906. https://doi. org/10.3390/ijms150814891.

55. Pratelli R, Guerra DD, Yu S, Wogulis M, Kraft E, Frommer WB, et al. The ubiquitin E3 ligase LOSS OF GDU2 is required for GLUTAMINE DUMPER1induced amino acid secretion in Arabidopsis. Plant Physiol. 2012;158(4): 1628-42. https://doi.org/10.1104/pp.111.191965.

56. Lee SK, Jeon JS. Review: Crucial role of inorganic pyrophosphate in integrating carbon metabolism from sucrose breakdown to starch synthesis in rice endosperm. Plant Sci. 2020;298:1 10572. https://doi.org/10.1016/.jpla ntsci.2020.110572.

57. Steppuhn H, Acharya SN, Iwaasa AD, Gruber M, Miller DR. Inherent responses to root-zone salinity in nine alfalfa populations. Can J Plant Sci. 2012;92(2):235-48. https://doi.org/10.4141/cjps2011-174.

58. Peel MD, Waldron BL, Jensen KB, Chatterton NJ, Horton H, Dudley LM. Screening for salinity tolerance in alfalfa. Crop Sci. 2004;44(6):2049-53. https://doi.org/10.2135/cropsci2004.2049.

59. Rahman MA, Alam I, Kim YG, Ahn NY, Heo SH, Lee DG, et al. Screening for salt responsive proteins in two contrasting alfalfa cultivars using a 
comparative proteome approach. Plant Physiol Biochem. 2015;89:112-22. https://doi.org/10.1016/j.plaphy.2015.02.015.

60. Schmieder R, Edwards R. Quality control and preprocessing of metagenomic datasets. Bioinformatics. 2011;27(6):863-4. https://doi.org/10.1 093/bioinformatics/btr026.

61. Bolger AM, Lohse M, Usadel B. Trimmomatic: a flexible trimmer for Illumina sequence data. Bioinformatics. 2014;30(15):2114-20. https://doi.org/10.1093/ bioinformatics/btu170.

62. Chen $H$, Zeng $Y$, Yang $Y$, Huang $L$, Tang B, Zhang H, et al. Allele-aware chromosome-level genome assembly and efficient transgene-free genome editing for the autotetraploid cultivated alfalfa. Nat Commun. 2020;11(1): 2494. https://doi.org/10.1038/s41467-020-16338-x.

63. Zeng Y. Genome fasta sequence and annotation files. figshare. Dataset; 2020. https://doi.org/10.6084/m9.figshare.12327602.v3. Accessed 28 Dec 2020

64. Dobin A, Davis CA, Schlesinger F, Drenkow J, Zaleski C, Jha S, et al. STAR: ultrafast universal RNA-seq aligner. Bioinformatics. 2013;29(1):15-21. https:// doi.org/10.1093/bioinformatics/bts635.

65. Love Ml, Huber W, Anders S. Moderated estimation of fold change and dispersion for RNA-seq data with DESeq2. Genome Biol. 2014;15(12):550 https://doi.org/10.1186/s13059-014-0550-8.

66. Tian T, Liu Y, Yan H, You Q, Yi X, Du Z, et al. AgriGO v2.0: a GO analysis toolkit for the agricultural community, 2017 update. Nucleic Acids Res. 2017; 45(W1):W122-9. https://doi.org/10.1093/nar/gkx382.

67. Oliveros JC. VENNY. An interactive tool for comparing lists with Venn Diagrams. 2007. https://bioinfogp.cnb.csic.es/tools/venny/index.html. Accessed 28 Feb 2021.

68. Garrison E, Marth G. Haplotype-based variant detection from short-read sequencing. 2012. arXiv:1207.3907.

69. Krzywinski M, Schein J, Birol I, Connors J, Gascoyne R, Horsman D, et al. Circos: an information aesthetic for comparative genomics. Genome Res. 2009;19(9):1639-45. https://doi.org/10.1101/gr.092759.109.

\section{Publisher's Note}

Springer Nature remains neutral with regard to jurisdictional claims in published maps and institutional affiliations.

Ready to submit your research? Choose BMC and benefit from:

- fast, convenient online submission

- thorough peer review by experienced researchers in your field

- rapid publication on acceptance

- support for research data, including large and complex data types

- gold Open Access which fosters wider collaboration and increased citations

- maximum visibility for your research: over $100 \mathrm{M}$ website views per year

At $\mathrm{BMC}$, research is always in progress.

Learn more biomedcentral.com/submissions 